\title{
Could Antinuclear Antibody Positivity Be a Factor Affecting Treatment Response in Immune Thrombocytopenia Patients on Eltrombopag?
}

\author{
Anti-Nükleer Antikor Pozitifliği Eltrombopag Kullanan Immün Trombositopeni Hastalarında \\ Tedavi Yanıtını Etkileyen Bir Faktör Olabilir mi?
}

(D) Mehmet Baysal, (D) Volkan Baş, (D) Elif Ümit, (D) Hakkı Onur Kırkızlar, (D) Ahmet Muzaffer Demir

Trakya University Faculty of Medicine, Department of Hematology, Edirne, Turkey

\section{Abstract}

Objective: Eltrombopag remains a prominent option in the treatment of steroid-dependent or steroid-refractory immune thrombocytopenia (ITP) patients. Unfortunately, not all patients respond to eltrombopag. Antinuclear antibody (ANA) positivity can be seen at rates of up to $30 \%$ in ITP patients. Despite being widely used, more markers to predict the response to eltrombopag are still needed. In the present study, we aimed to show the association between ANA positivity and eltrombopag response in ITP patients.

Materials and Methods: Patients who were diagnosed with ITP in the Trakya University Faculty of Medicine's Department of Hematology and who underwent eltrombopag treatment due to their resistance to steroids and other treatments were included in our study. ANA measurement was performed by indirect fluorescent antibody method and titers of 1:160 and above were considered positive. ANA measurements were made before starting eltrombopag.

Results: Forty-five patients were included in our study, 33 being women and 12 men. The mean age of the patients was 45.73 years. There were 14 patients with ANA positivity and 31 patients were found to be ANA-negative. Response rates were higher in ANA-negative patients compared to ANA-positive patients in the $1^{\text {st }}$ and $6^{\text {th }}$ months of eltrombopag treatment $(p<0.05)$.

Conclusion: ANA positivity in ITP may indicate unresponsiveness to eltrombopag treatment, a finding that should be further supported by prospective studies involving more patients.

Keywords: Antinuclear antibodies, Eltrombopag, Immune thrombocytopenia
III

Öz

Amaç: Eltrombopag, steroide bağımlı veya steroide dirençli immün trombositopeni (ITP) hastalarının tedavisinde önemli bir seçenek olmaya devam etmektedir. Ne yazık ki, bir grup hastada eltrombopag ile istenen yanıt oranları elde edilmemektedir. Antinükleer antikor (ANA) pozitifliği ITP hastalarında \%30'a kadar görülebilmektedir. Yaygın olarak kullanılmasına rağmen, eltrombopag yanıtını gösteren belirteçler net değildir.Bu çalışmada ITP hastalarında ANA pozitifliği ile eltrombopag yanıtı arasındaki ilişkiyi göstermeyi amaçladık.

Gereç ve Yöntemler: Trakya Üniversitesi Tıp Fakültesi Hematoloji Bölümü'nde ITP tanısı alan ve steroid ve diğer tedavilere dirençli olmaları nedeniyle eltrombopag tedavisi alan hastalar çalışmamıza dahil edildi. ANA ölçümü eltrombopag tedavisi öncesinde gerçekleştirildi ve indirekt floresan antikor ile yapıldı. ANA için 1:160 ve üzeri titreler pozitif kabul edildi.

Bulgular: Çalışmamıza 45 hasta dahil edildi. Hastaların 33'ü kadın, 12 'si erkekti. Hastaların yaş ortalaması 45,73 idi. ANA pozitif olan 14 ve negatif olan 31 hasta vardı. Eltrombopag tedavisinin birinci ve altıncı aylarında ANA negatif hastalarda ANA pozitif hastalara göre yanıt oranları daha yüksek olarak saptandı $(p<0,05)$.

Sonuç: ITP'de ANA pozitifliğinin eltrombopag tedavisine yanıtsızlığa işaret edebileceğini ve bu durumun daha fazla hastayı içeren prospektif çalışmalarla desteklenmesi gerektiğini düşünmekteyiz.

Anahtar Sözcükler: Anti-nükleer antikorlar, Eltrombopag, İmmün trombositopeni 


\section{Introduction}

Immune thrombocytopenia (ITP) is an autoimmune disease characterized by a low platelet count caused by increased destruction of thrombocytes due to platelet autoantibodies and impaired platelet production $[1,2]$. The diagnosis of ITP is made by exclusion. Primary ITP occurs without an underlying disease, while secondary ITP is defined as ITP occurring with an underlying disease or facilitating factor [3]. The antibodies that target proteins within the nucleus of a cell are called antinuclear antibodies (ANAs). ANA positivity can be detected in about 5\%-10\% of healthy individuals $[4,5]$, while ANA positivity was reported at rates between $15 \%$ and $39 \%$ in studies conducted with ITP patients $[6,7,8]$. It has also been reported that ANA positivity in ITP patients is associated with a more chronic course and the risk of developing more autoimmune diseases [9]. Accordingly, testing for ANA was suggested as being of potential utility according to an international consensus report on the investigation and management of primary ITP [10]. The first-line treatment of ITP consists of corticosteroids and intravenous immunoglobulin. For patients who are corticosteroid-dependent or who do not have a response to corticosteroids, the recommended treatment options are thrombopoietin receptor agonists (TPO-RAs), splenectomy, and rituximab [11]. Eltrombopag and romiplostim are the currently licensed TPO-RAs for ITP. Eltrombopag is an orally available nonpeptide TPO-RA and is accessible in Turkey.

Approximately $10 \%$ to $30 \%$ of patients receiving eltrombopag have a permanent improvement in platelet values and drug administration can be discontinued [12]. However, some patients may be unresponsive to TPO-RAs [13]. In some cases, the addition of small doses of steroids to TPO-RAs may be required to maintain thrombocyte levels [14]. The variety of responses to TPO-RAs indicates the need for factors to be identified for prediction. Regarding such factors, ANA was suggested as a test of potential utility according to an international consensus report; however, the real utility of positive ANA test results in ITP patients has yet to be determined. The results of studies on the effect of ANA positivity on treatment in ITP are conflicting $[15,16,17]$. Because ANAs are antibodies demonstrating a predisposition to autoimmunity, ANA positivity may affect the response rates in patients with ITP who receive eltrombopag treatment. In the present study, we aim to investigate the association between ANA positivity and eltrombopag response in patients with ITP.

\section{Materials and Methods}

Patients who were diagnosed with ITP in the Trakya University Faculty of Medicine's Hematology Department and who underwent eltrombopag treatment due to their resistance to steroids and other treatments were included in this study. The starting dose in eltrombopag treatment is $50 \mathrm{mg}$ once a day; for patients who do not respond with $50 \mathrm{mg}$, the dose is increased to $75 \mathrm{mg}$ daily. If the platelet count exceeds $250,000 \times 10^{9} / \mathrm{L}$, treatment is stopped. For patients whose treatment is discontinued because the platelet count exceeds 250,000, the treatment is restarted with a daily dose of $25 \mathrm{mg}$ when the thrombocyte count falls below 100,000. ANA measurements were made by indirect fluorescent antibody method and titers of 1:160 and above were considered positive. All other investigations performed for patients with ITP were recorded from their hospital files. Hepatitis $B$, hepatitis $C$, and HIV serology of the patients were evaluated. Serum immunoglobulin $\mathrm{G}$ levels and direct antiglobulin tests were also reviewed. ANA-positive patients were also evaluated for other clinical and laboratory findings of systemic lupus erythematosus [18]. Response criteria were as follows: (1) complete response (CR): platelet count of $\geq 100 \times 10^{9} / \mathrm{L}$ and no bleeding; (2) response (R): platelet count of $\geq 30 \times 10^{9} / \mathrm{L}$ and no bleeding; (3) no response: platelet count of $<30 \times 10^{9} / \mathrm{L}$ or bleeding. Recurrence was defined as a decrease in platelet count to $<30 \times 10^{9} / \mathrm{L}$ and/or bleeding in responders [3]. Ethical approval to conduct the study was obtained from the institutional review board and the study was carried out in accordance with the 1964 Declaration of Helsinki and its later amendments. Patients who could not achieve a response with eltrombopag were administered rituximab at $375 \mathrm{mg} / \mathrm{m}^{2}$ for 4 weeks as an additional treatment for ITP.

\section{Statistical Analysis}

For statistical analysis, SPSS 22.0 (IBM Corp., Armonk, NY, USA) was used and a two-sided $p$-value below or equal to 0.05 was considered statistically significant. Descriptive statistics were given as number, percentage, and mean \pm standard deviation. Chi-square and Fisher exact tests were used in the analysis of categorical variables. Chi-square contingency analysis was also performed due to the small sample size. Continuous variables were compared using the Mann-Whitney $\mathrm{U}$ test.

\section{Results}

A total of 45 patients were included in our study; 33 were female and 12 were male. The mean age of the patients was 45.73 years. There were 14 patients with ANA positivity and 31 patients were found to be ANA-negative. Demographic and clinical findings are given in Table 1. Of the 14 ANA-positive patients, 13 were female and 1 was male. Of the 31 ANA-negative patients, 20 were female and 11 were male. Detailed demographic data of the patients according to ANA positivity are given in Table 2 . Response rates of the patients were evaluated according to their thrombocyte count during the $1^{\text {st }}$ month, $3^{\text {rd }}$ month, and $6^{\text {th }}$ month of treatment. Response assessments are presented in Table 3. One patient developed pulmonary emboli and grade 3 hyperbilirubinemia occurred in another patient; eltrombopag 


\begin{tabular}{|l|l|}
\hline \multicolumn{2}{|l|}{ Table 1. Demographic and clinical data of the patients. } \\
\hline Parameter & Number (\%) \\
\hline $\begin{array}{l}\text { Gender } \\
\text { Female } \\
\text { Male }\end{array}$ & $33(73 \%)$ \\
\hline Age, mean (minimum-maximum) & $12(27 \%)$ \\
\hline $\begin{array}{l}\text { ANA-positive } \\
\text { ANA-negative }\end{array}$ & $45.73 \pm 18.86(18-85)$ \\
\hline $\begin{array}{l}\text { Mean platelet count before eltrombopag } \\
\text { treatment, } x 10 \% / L\end{array}$ & $31(69 \%)$ \\
\hline $\begin{array}{l}\text { Number of prior line of therapies } \\
\text { One }\end{array}$ & $13.9 \pm 7.2$ \\
Two & $39(87 \%)$ \\
\hline Splenectomy before eltrombopag & $6(13 \%)$ \\
\hline $\begin{array}{l}\text { Concomitant ITP treatment with } \\
\text { eltrombopag }\end{array}$ & $4(6.6 \%)$ \\
\hline Rituximab treatment before eltrombopag & $3(6.6 \%)$ \\
\hline ANA: Antinuclear antibody; ITP: immune thrombocytopenia. \\
\hline
\end{tabular}

treatment was discontinued in both cases. Therefore, at 6 months, the analysis was performed with 43 patients. Response rates were higher in ANA-negative patients than ANA-positive patients in the $1^{\text {st }}$ and $6^{\text {th }}$ months of eltrombopag treatment $(p<0.05)$.

\section{Discussion}

Various autoimmune antibodies have been shown to be more positive in ITP patients than in healthy individuals. Positive ANA tests in ITP patients were associated with poor response to steroids and a more chronic disease outcome $[7,9,15]$. Similar to this finding, in a retrospective analysis that included 1330 cases of chronic childhood ITP, ANA positivity was associated with more persistent and chronic disease [19]. In another recent study, ANA positivity was associated with a higher risk for thrombosis in ITP patients [16]. In that analysis, positive ANA test results were obtained in 65\% of the study population. The cut-off for positive ANA titer was taken as 1:40 or above.

\begin{tabular}{|l|l|l|l|}
\hline \multicolumn{2}{|l|}{ Table 2. Detailed demographic data and thrombocyte counts of the patients according to ANA positivity. } \\
\hline & $\begin{array}{l}\text { ANA-positive patients } \\
\mathbf{n}: 14\end{array}$ & $\begin{array}{l}\text { ANA-negative patients } \\
\mathbf{n}: 31\end{array}$ & $\mathbf{p}$ \\
\hline $\begin{array}{l}\text { Gender } \\
\text { Female } \\
\text { Male }\end{array}$ & 13 & 20 & \multirow{2}{*}{0.070} \\
\hline Age & 1 & 11 & 0.950 \\
\hline Baseline thrombocyte count, $\times 10^{9} / \mathrm{L}$ & 46 & 45.6 & 0.724 \\
\hline Thrombocyte count at 1st month, $\times 10^{9} / \mathrm{L}$ & $13.4(4-14-26)$ & $14.2(4-14-29)$ & 0.035 \\
\hline Thrombocyte count at $3^{\text {rd }}$ month, $\times 10^{9} / \mathrm{L}$ & $77.2(9-53-288)$ & $159.8(12-127-646)$ & 0.783 \\
\hline Thrombocyte count at $6^{\text {th }}$ month, $\times 10^{9} / \mathrm{L}$ & $144.1(15-107-495)$ & $144.4(3-110-523)$ & 0.133 \\
\hline History of splenectomy before eltrombopag & $104.1(12-109-295)$ & $156.3(31-143-577)$ & 0.368 \\
\hline Additional rituximab treatment with eltrombopag & $2(14.2 \%)$ & $1(3.2 \%)$ & 0.459 \\
\hline Rituximab treatment before eltrombopag & $3(21.4 \%)$ & $1(3.2 \%)$ & 0.368 \\
\hline Duration of ITP, months, median (minimum-maximum) & $43(11-211)$ & $1(3.2 \%)$ & 0.203 \\
\hline ANA: Antinuclear antibody; ITP: immune thrombocytopenia. & $2(14.2 \%)$ & $30(6-201)$ & \\
\hline
\end{tabular}

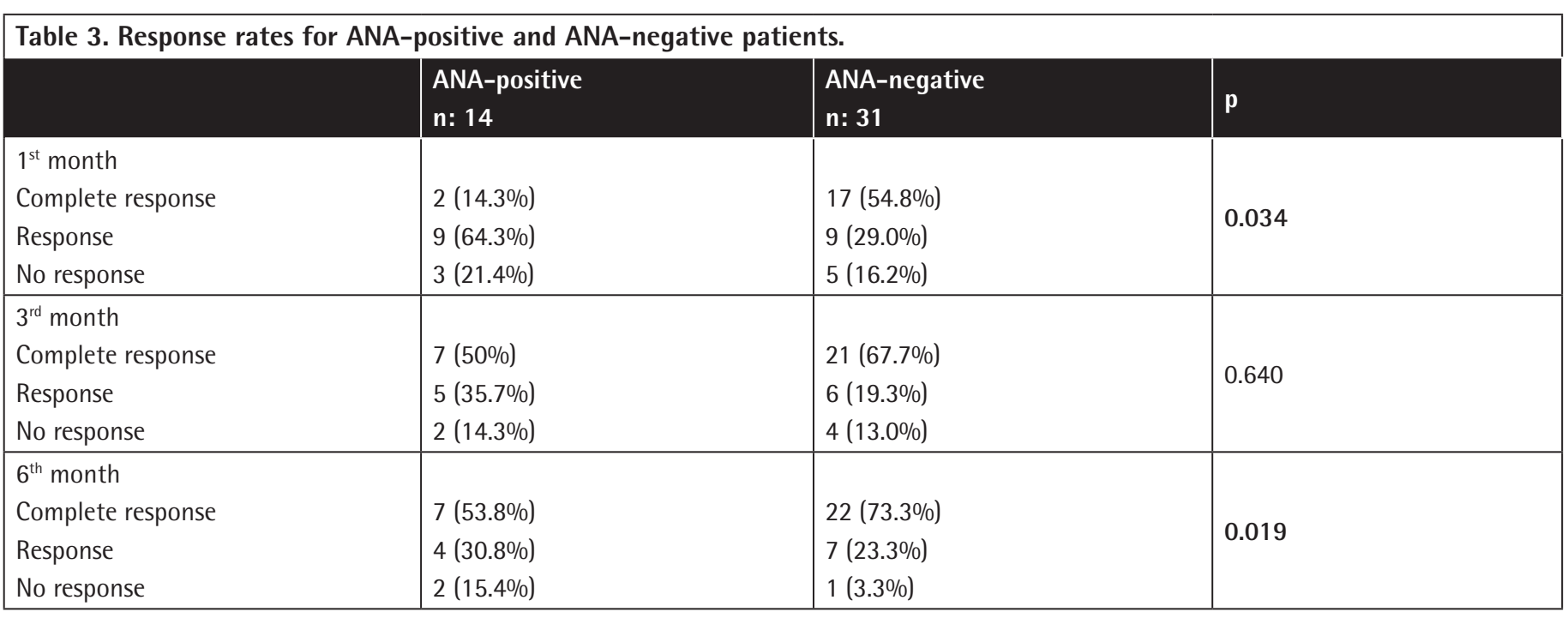


It was also observed that when ANA positivity was taken as a titer of 1:80, the rate of ANA positivity decreased to $44 \%$. In another retrospective analysis, ANA positivity was found in 24.4\% of the patients and ANA-positive patients had a poorer response to initial steroid therapy compared to ANA-negative patients [14]. In our analysis, ANA positivity was found in $31 \%$ of cases, similar to the data in the literature. A recent prospective study included 278 primary ITP patients, and in that registry, neither complete response rates nor thrombosis during follow-up periods were different for ANA-positive and ANA-negative patients [17]. In another retrospective analysis, the authors aimed to show differences in responses in primary ITP patients receiving rituximab therapy. ANA-positive patients tended to respond better compared to ANA-negative patients in the initial evaluation in the $1^{\text {st }}$ month [20]. ANA-positive patients constituted $34.1 \%$ of the study population. However, ANA-positive patients' response rates waned with time in the follow-up period and the response rates of ANA-negative patients in the $6^{\text {th }}, 12^{\text {th }}$, and $24^{\text {th }}$ months were found to be better [20]. In our analysis, ANA-positive patients' response rates were lower in the $1^{\text {st }}$ month, similar in the $3^{\text {rd }}$ month, and lower in the $6^{\text {th }}$ month compared to ANA-negative patients. Although the follow-up period in our study was shorter than that of the previously mentioned study [17], we also showed that response rates decreased over time in ANA-positive patients who received eltrombopag treatment. The efficacy of eltrombopag treatment in chronic ITP was also demonstrated in studies using real-world data $[21,22,23]$. Nevertheless, some patients do not respond well to eltrombopag therapy. Factors and indicators that can predict response rates should be identified. Our study population included steroid-resistant or steroid-dependent patients, which could be another factor for the low response rates seen in ANApositive patients. The two main limitations of our study are the short follow-up period and small sample size.

\section{Conclusion}

ANA positivity in ITP may indicate unresponsiveness to eltrombopag treatment, and this should be supported by prospective studies involving more patients.

\section{Ethics}

Ethics Committee Approval: Ethical approval to conduct the study was obtained from the institutional review board and the study was carried out in accordance with the 1964 Declaration of Helsinki and its later amendments.

Informed Consent: Written informed consent was obtained from all patients.

\section{Authorship Contributions}

Concept: M.B.; Design: M.B., E.Ü.; Data Collection or Processing: V.B., M.B.; Analysis or Interpretation: H.O.K., A.M.D.; Literature Search: M.B.; V.B.; Writing: M.B., E.Ü.
Conflict of Interest: No conflict of interest was declared by the authors.

Financial Disclosure: The authors declared that this study received no financial support.

\section{References}

1. Lambert MP, Gernsheimer TB. Clinical updates in adult immune thrombocytopenia. Blood 2017;129:2829-2835.

2. Cooper N, Ghanima W. Immune thrombocytopenia. N Engl J Med 2019;381:945-955.

3. Rodeghiero F, Stasi R, Gernsheimer T, Michel M, Provan D, Arnold DM, Bussel JB, Cines DB, Chong BH, Cooper N, Godeau B, Lechner K, Mazzucconi MG, McMillan R, Sanz MA, Imbach P, Blanchette V, Kühne T, Ruggeri M, George JN. Standardization of terminology, definitions and outcome criteria in immune thrombocytopenic purpura of adults and children: report from an international working group. Blood 2009;113:2386-9233.

4. Tan EM, Feltkamp TE, Smolen JS, Butcher B, Dawkins R, Fritzler MJ, Gordon T, Hardin JA, Kalden JR, Lahita RG, Maini RN, McDougal JS, Rothfield NF, Smeenk RJ, Takasaki Y, Wiik A, Wilson MR, Koziol JA. Range of antinuclear antibodies in "healthy" individuals. Arthritis Rheum 1997;40:1601-1611.

5. Guo YP, Wang CG, Liu X, Huang YQ, Guo DL, Jing XZ, Yuan CG, Yang $S$, Liu JM, Han MS, Li HX. The prevalence of antinuclear antibodies in the general population of China: a cross-sectional study. Cur Ther Res Clin Exp 2014;76:116-119.

6. Grimaldi-Bensouda L, Nordon C, Michel M, Viallard JF, Adoue D, MagyBertrand N, Durand JM, Quittet P, Fain O, Bonnotte B, Morin AS, Morel N, Costedoat-Chalumeau N, Pan-Petesch B, Khellaf M, Perlat A, Sacre K, Lefrere F, Abenhaim L, Godeau B; Group for the PGRx-ITP Study. Immune thrombocytopenia in adults: a prospective cohort study of clinical features and predictors of outcome. Haematologica 2016;101:1039-1045.

7. Moulis G, Germain J, Comont T, Brun N, Dingremont C, Castel B, Arista S, Sailler L, Lapeyre-Mestre M, Beyne-Rauzy 0, Godeau B, Adoue D; CARMEN Investigators Group. Newly diagnosed immune thrombocytopenia adults: Clinical epidemiology, exposure to treatments, and evolution. Results of the CARMEN multicenter prospective cohort. Am J Hematol 2017;92:493-500.

8. Demir C, Esen R, Atmaca M, Efe S. Prevalence of autoantibodies related to some autoimmune disorders in patients with chronic idiopathic thrombocytopenic purpura. Clin Appl Thromb Hemost 2011;17:E114-118.

9. Altintas A, Ozel A, Okur N, Okur N, Cil T, Pasa S, Ayyildiz O. Prevalence and clinical significance of elevated antinuclear antibody test in children and adult patients with idiopathic thrombocytopenic purpura. J Thromb Thrombolysis 2007;24:163-168.

10. Provan D, Stasi R, Newland AC, Blanchette VS, Bolton-Maggs P, Bussel JB, Chong BH, Cines DB, Gernsheimer TB, Godeau B, Grainger J, Greer I, Hunt BJ, Imbach PA, Lyons G, McMillan R, Rodeghiero F, Sanz MA, Tarantino M, Watson S, Young J, Kuter DJ. International consensus report on the investigation and management of primary immune thrombocytopenia. Blood 2010;115:168-186.

11. Neunert C, Terrell DR, Arnold DM, Buchanan G, Cines DB, Cooper N, Cuker A, Despotovic JM, George JN, Grace RF, Kühne T, Kuter DJ, Lim W, McCrae KR, Pruitt B, Shimanek H, Vesely SK. American Society of Hematology 2019 guidelines for immune thrombocytopenia. Blood Adv 2019;3:3829-3866.

12. Mahévas $M$, Fain 0 , Ebbo $M$, Roudot-Thoraval $F$, Limal $N$, Khellaf $M$, Schleinitz N, Bierling P, Languille L, Godeau B, Michel M. The temporary use of thrombopoietin-receptor agonists may induce a prolonged remission in adult chronic immune thrombocytopenia. Results of a French observational study. Br J Haematol 2014;165:865-869.

13. Khellaf $M$, Michel $M$, Quittet $P$, Viallard JF, Alexis $M$, Roudot-Thoraval $F$, Cheze S, Durand JM, Lefrère F, Galicier L, Lambotte 0 , Panelatti G, Slama B, 
Damaj G, Sebahoun G, Gyan E, Delbrel X, Dhedin N, Royer B, Schleinitz N, Rossi JF, Mahévas M, Languille L, Bierling P, Godeau B. Romiplostim safety and efficacy for immune thrombocytopenia in clinical practice: 2-year results of 72 adults in a romiplostim compassionate-use program. Blood 2011;118:4338-4345.

14. Gomez-Almaguer D, Colunga-Pedraza PR, Gomez-De Leon A, GutierrezAguirre CH, Cantu-Rodriguez OG, Jaime-Perez JC. Eltrombopag, low-dose rituximab, and dexamethasone combination as frontline treatment of newly diagnosed immune thrombocytopaenia. Br J Haematol 2019;184:288-290.

15. Abbasi SY, Milhem M, Zaru L. A positive antinuclear antibody test predicts for a poor response to initial steroid therapy in adults with idiopathic thrombocytopenic purpura. Ann Hematol 2008;87:459-462.

16. Hollenhorst MA, Al-Samkari $H$, Kuter DJ. Markers of autoimmunity in immune thrombocytopenia: prevalence and prognostic significance. Blood Adv 2019;3:3515-3521.

17. Moulis G, Comont T, Germain J, Sommet A, Lapeyre-Mestre M, Beyne-Rauzy 0 , Adoue D; CARMEN Investigators Group. Significance of antinuclear antibodies in primary immune thrombocytopenia: results of the CARMEN registry. Blood Adv 2020;4:1974-197.

18. Aringer M, Costenbader K, Daikh D, Brinks R, Mosca M, Ramsey-Goldman R, Smolen JS, Wofsy D, Boumpas DT, Kamen DL, Jayne D, Cervera R, CostedoatChalumeau N, Diamond B, Gladman DD, Hahn B, Hiepe F, Jacobsen S, Khanna D, Lerstrøm K, Massarotti E, McCune J, Ruiz-Irastorza G, SanchezGuerrero J, Schneider M, Urowitz M, Bertsias G, Hoyer BF, Leuchten N, Tani C, Tedeschi SK, Touma Z, Schmajuk G, Anic B, Assan F, Chan TM, Clarke AE, Crow MK, Czirják L, Doria A, Graninger W, Halda-Kiss B, Hasni S, Izmirly PM, Jung M, Kumánovics G, Mariette X, Padjen I, Pego-Reigosa JM, Romero-Diaz J, Rúa-Figueroa Fernández Í, Seror R, Stummvoll GH, Tanaka Y, Tektonidou MG, Vasconcelos C, Vital EM, Wallace DJ, Yavuz S, Meroni PL, Fritzler MJ, Naden R, Dörner T, Johnson SR. 2019 European League Against Rheumatism/ American College of Rheumatology classification criteria for systemic lupus erythematosus. Arthritis Rheumatol 2019;71:1400-1412.
19. Liu Q, Xu H, Guan X, Shen $Y$, Wen $X$, Guo $Y$, et al. Clinical significance of antinuclear and antiextractable nuclear antigen antibody in childhood immune thrombocytopenia. Semin Thromb Hemost 2017;43:629-634.

20. Wang YM, Yu YF, Liu Y, Liu S, Hou M, Liu XG. The association between antinuclear antibody and response to rituximab treatment in adult patients with primary immune thrombocytopenia. Hematology 2020;25:139-144.

21. Özdemirkıran F, Payzın B, Kiper HD, Kabukçu S, Akgün Çağlıyan G, Kahraman S, Sevindik ÖG, Ceylan C, Kadıköylü G, Şahin F, Keskin A, Arslan Ö, Özcan MA, Kabukçu G, Görgün G, Bolaman Z, Büyükkeçeci F, Bilgir O, Alacacıoğlu i, Vural F, Tombuloğlu M, Gökgöz Z, Saydam G. Eltrombopag for the treatment of immune thrombocytopenia: the Aegean region of Turkey experience. Turk J Hematol 2015;32:323-328.

22. Çekdemir D, Güvenç $S$, Özdemirkıran $F$, Eser $A$, Toptaş $T$, Özkocaman $V$, Haydaroğlu Şahin $H$, Ermiş Turak E, Esen R, Cömert $M$, Sadri $S$, Aslaner $M$, Uncu Ulu B, Karakuş A, Selim Bapur D, Alacacıoğlu i, Aydın D, Tekinalp A, Namdaroğlu S, Ceran F, Tarkun P, Kiper D, Çetiner M, Yenerel M, Demir AM, Yılmaz G, Terzi H, Atilla E, Malkan ÜY, Acar K, Öztürk E, Tombak A, Sunu C, Salim O, Alayvaz N, Sayan Ö, Ozan Ü, Ayer M, Gökgöz Z, Andıç N, Kızılkıııç E, Noyan F, Özen M, Pepedil Tanrıkulu F, Alanoğlu G, Özkan HA, Aslan V, Çetin G, Akyol Erikçi A, Deveci B, Ersoy Dursun F, Dermenci H, Aytan P, Gündüz M, Karakuş V, Özlü C, Demircioğlu S, Akay Yanar OM, Özatı D, Ündar L, Tiftik EN, Türköz Sucak AG, Haznedaroğlu İ, Özcan $M$, Şencan $M$, Tombuloğlu $M$, Özet G, Bilgir O, Turgut B, Özcan MA, Payzın KB, Sönmez M, Ayyıldız O, Dal $M S$, Ertop Ş, Turgut $M$, Soysal $T$, Kaya $E$, Ünal $A$, Pehlivan $M$, Atagündüz I, Tuğlular Fıratlı T, Saydam G, Diz Küçükkaya R. A multi-center study on the efficacy of eltrombopag in management of refractory chronic immune thrombocytopenia: a real-life experience. Turk J Hematol 2019;36:230-237.

23. Ghanima W, Cooper N, Rodeghiero F, Godeau B, Bussel JB. Thrombopoietin receptor agonists: ten years later. Haematologica 2019;104:1112-1123. 